\title{
Analisis Kesalahan Siswa SMP Berdasarkan Newman dalam Menyelesaikan Soal Kemampuan Berpikir Kritis Matematis pada Materi Bangun Ruang Sisi datar
}

\author{
Iwan Darmawan ${ }^{1}$, Anis Kharismawati ${ }^{2}$, Heris Hendriana ${ }^{3}$, Ratni Purwasih ${ }^{4}$ \\ ${ }_{1,2,3,4}$ Institut Keguruan dan Ilmu Pendidikan Siliwangi Bandung \\ ${ }^{1}$ iwandarmawan. teachers@yahoo.co. id, ${ }^{4}$ ratnipurwasih@ikipsiliwangi. ac. id
}

\begin{abstract}
This study used a qualitative approach and the type of research conducted is descriptive. Taking the subjects of this study were 33 students of class IX SMP Negeri 16 Bandung academic year 2017/2018. Based on the results of data analysis shows that no students can answer correctly all the questions that have been given. Based on data analysis, it can be concluded that reading error $13.0 \%$, comprehension 3. 7\%, transformation $12.2 \%$, skill $9.7 \%$, writing final answer 16 . $3 \%$ and carelessness $7.7 \%$, errors done by students include: Newman's procedure is reading errors, comprehension errors, transformation errors, process skills errors, and errors in encoding errors and careless errors. The cause factor is not able to compose the meaning of the word thought into the form of a sentence matamatika, not understand the questions asked, less thorough, less able to capture information problems contained in the problem, forgot, lack of practice working on various story form problems.
\end{abstract}

Keywords: Error, solve story problem, critical, Build Space flat side, newman

\section{PENDAHULUAN}

Mata pelajaran matematika salah satunya bertujuan agar siswa memiliki sikap menghargai kegunaan matematika dalam kehidupan, yaitu memiliki rasa ingin tahu, perhatian, dan minat dalam mempelajari matematika, serta sikap ulet dan percaya diri dalam pemecahan masalah. Menurut Sariningsih \& Purwasih (2017) pendidikan matematika dapat mendorong masyarakat untuk selalu maju, terbukti dengan adanya perkembangan teknologi modern. Oleh karena itu, belajar matematika dengan baik merupakan langkah pertama dalam penguasaan konsep. Sedangkan matematika itu sendiri menurut satoto, sutarto \& pujiastuti (2013) mengemukakan bahwa Matematika merupakan ilmu tentang struktur yang terorganisasikan dengan baik. Mata pelajaran matematika perlu diberikan kepada semua siswa dengan tujuan untuk mengembangkan kemampuan berpikir siswa dan memberikan pengetahuan matematika dasar. Pada tahap awal, siswa diperkenalkan kepada matematika yang bersifat informal. Pada jenjang menengah, pelajaran matematika bertujuan mengenalkan dasar-dasar matematika sebagai ilmu. . Sejalan dengan tahap perkembangan mereka, siswa diperkenalkan secara bertahap kepada matematika yang bersifat formal. Selaras dengan pendapat Khatimah, Sa'dijah, \& Susanto (2017) Matematika merupakan salah satu ilmu dasar yang diberikan sejak pendidikan dasar sampai sekolah menengah, dimana matematika memiliki fungsi yang sangat penting dalam kehidupan sehari-hari. Hampir semua bidang studi menggunakan matematika sebagai alat bantu dalam memecahkan masalah. Namun, banyak siswa yang merasa tidak senang dalam mempelajari matematika. Hal ini disebabkan karena matematika bersifat abstrak.

Permasalahan dalam kehidupan sehari-hari yang terkait dengan matematika biasanya dituangkan dalam soal cerita. Soal cerita matematika memberikan gambaran yang nyata Permasalahan dalam kehidupan sehari-hari yang merupakan permasalahan kehidupan yang sebenarnya. Sedangkan, menurut Royani (2008) menyatakan soal cerita matematika merupakan 
soal-soal matematika yang menggunakan bahasa verbal dan umumnya berhubungan dengan kegiatan sehari-hari.

Namun, menurut Karnasih (2015) Salah satu permasalahan dalam menyelesaikan soal-soal matematika adalah soal matematika yang menggunakan katakata atau soal cerita (word problems). Selaras dengan peneliti ketika melaksanakan penelitian hibah dosen dan mahasiswa dari dikti soalsoal berupa cerita ini malah menjadi kelemahan siswa artinya siswa banyak kesulitan menafsirkan makna dalam soal tersebut. Oleh karena itu untuk mengetahui alasan yang menyebabkan siswa kesulitan dalam memahami soal. Terutama pada bentuk soal cerita maka perlu dilakukan analisis kesalahan siswa dalam pengerjaan soal. Selaras dengan pendapat Hendriana (2014). mengemukakan kenyataan bahwa kemampuan kompetensi strategis matematis siswa saat ini masih rendah. Terbukti dari masih sulitnya siswa untuk menyajikan masalah dalam kehidupan sehari-hari ke dalam model matematis dan menentukan strategi yang tepat untuk menyelesaikannya.

\section{TINJAUAN LITERATUR}

Metode analisis kesalahan Newman diperkenalkan pertama kali pada tahun 1977 oleh Anne Newman, seorang guru bidang studi matematika di Australia. Dalam metode ini, dia menyarankan lima kegiatan yang spesifik sebagai suatu yang sangat krusial untuk membantu menemukan di mana kesalahan yang terjadi pada pekerjaan siswa ketika menyelesaikan suatu masalah berbentuk soal cerita Prosedur Newman adalah sebuah metode untuk menganalisis kesalahan dalam soal uraian. Langkah-langkah yang harus dilakukan untuk menyelesaikan soal matematika menurut Newman yaitu membaca soal (reading), memahami masalah (comprehension), transformasi (transformation), keterampilan proses (process skill), dan penulisan jawaban (encoding).

Hakekat matematika adalah ilmu hitungan yang dapat membantu aktivitas manusia yang dikenal dengan buman as activity. Dalam matematika ada penggunaan rumus-rumus untuk penyelesaian suatu soal. Matematika juga merupakan proses berpikir secara kognitif dalam menghadapi permasalahan. Hal ini sejalan dengan Khalid (Aripin \& Purwasih, 2017) mengatakan bahwa berpikir matematis merupakan metode matematis dalam berpikir yang digunakan untuk menyelesaikan setiap masalah dalam kehidupan sehari-hari, termasuk di sekolah.

Untuk proses berpikir secara matematis melalui implementasi konsep yang ada dalam pelajaran matematika untuk memenuhi kebutuhan hidup sehari-hari. Pada dasarnya matematika tidak focus dalam ilmu hitungan saja melainkan melatih pola pikir secara nalar agar siswa memiliki kemampuan berpikir yang kreatif, kritis dan logik. Soedjadi (Alimuddin, 2009) menyatakan bahwa salah satu fungsi matematika sekolah adalah sebagai sarana penataan nalar peserta didik. Alviano (Sumarmo, 2010a) menyatakan bahwa berpikir kreatif adalah sebagian cara melihat atau melakukan sesuatu diklasifikasikan dalam empat komponen yaitu (1) kelancaran (fluency) membuat berbagai ide; (2) kelenturan (flexibility) kelihaian memandang ke depan dengan mudah; (3) keaslian (originality) menyusun sesuatu yang baru; (4) elaborasi (elaboration) membangun sesuatu dari ideide yang lain.

\section{METODE}

Tempat penelitian dilaksanakan di SMP Negeri 16 Bandung. Penelitian ini dilaksanakan pada bulan januari 2018. Penelitian ini tergolong dalam penelitian deskriptif kualitatif yang berupaya untuk mendeskripsikan analisis kesalahan siswa smp kelas IX dalam menyelesaikan soal cerita matematika pada materi bangun ruang sisi datar berdasarkan analisis newman. Subyek penelitian diambil dari siswa kelas IX SMP Negeri 16 Bandung Tahun ajaran 2017/2018 sebanyak tiga puluh tiga siswa, data penelitian yang dikumpulkan berupa informasi tentang kesalahan yang dilakukan peserta didik dalam menyelesaikan soal cerita matematika. Instrumen penelitian ini yaitu terdiri dari 7 soal uraian. Soal tes dalam penelitian ini berbentuk soal cerita yang berkaitan 
dengan Bangun Ruang sisi datar dan diusahakan soal tes tersebut mencakup kemungkinan siswa melakukan kesalahan-kesalahan menurut tahapan analisis kesalahan Newman.

\section{HASIL}

Langkah pertama yang dilakukan dalam penelitian ini yaitu menyususn soal tes kemampuan berpikir kritis,selanjutnya soal dikonsultasikan kepada dosen pembimbing. kemudian soal di uji kan kepada 33 siswa dengan waktu 90 menit. Selanjutnya, data diolah dan dianalisis berdasarkan rubrik penskoran. Hasil analisis soal kemampuan berpikir kritis matematik dapat dilihat dari tabel 1.

Tabel 1. Analisis Soal Kemampuan Berpikir Kritis Matematik

\begin{tabular}{lcccccc}
\hline Indikator & $\mathbf{A}$ & $\mathbf{B}$ & $\mathbf{C}$ & $\mathbf{D}$ & $\mathbf{E}$ & $\mathbf{F}$ \\
\hline Sm1 & 4 & 4 & 4 & 4 & 4 & 4 \\
Rata-Rata & 0.73 & 1.91 & 2.76 & 3.21 & 1.48 & 1.36 \\
Presentase & $15 \%$ & $38 \%$ & $55 \%$ & $64 \%$ & $30 \%$ & $27 \%$ \\
\hline
\end{tabular}

Terlihat bahwa kemampuan berpikir kritis siswa masih rendah terlihat dari enam indikator yang diujikan hasil presentasinya kurang dari $60 \%$, lima indikator presentasina dibawah $60 \%$ dan yang sangat rendah adalah indikator A dan E. yaitu memiliki presentase sebesar 15\% dan 27\% indikator tersebut adalah reason dan focus. Faktornya adalah siswa belum bisa membaca soal, memahami masalah, transformasi, keterampilan proses, dan penulisan jawaban.

Sedangkan, kesalahan dalam menelesaikan soal cerita pokok bangun ruang sisi datar terlihat dalam tabel 2 dengan data yang diperoleh setelah siswa menyelesaikan tes tertulis. data yang diperoleh berupa lembar jawaban tertulis yang merupakan hasil pengerjaan siswa data ini dapat digunakan juga untuk identifikasi jenis kesalahan siswa

Pada tabel 2, dapat terlihat bahwa pada soal no 1 sebanyak 22 siswa melakukan kesalahan membaca soal dalam hal ini siswa belum mampu memaknai kalimat yang mereka baca dengan tepat. Sedangkan sebanyak 4 siswa juga tidak memahami soal soal no 2 dan 10 siswa tidak memahami soal no 3, mereka tidak dapat memahami apa yang diketahui dan ditanyakan dalam soal dengan baik. Sedangkan pada tahap transformasi pada soal no 4, 31 siswa dapat mentransformasi dengan baik tapi pada soal no 5 sebanyak 25 siswa yang tidak mampu mentransformasi kalimat matematika dalam soal cerita tersebut. Pada tahap ketrampilan proses hanya 3 siswa yang melakukan kesalahan pada soal no 1 begitu pula pada soal no 5 Sedangkan pada tahap penulisan jawaban akhir sekitar 8 siswa yang melakukan kesalahan dalam penulisan jawaban akhir. serta hana 1 siswa yang melakukan kecerobohan di soal no. 2. Berikut disajikan rekapitulasi presentase kesalahan yang dilakukan siswa.

Tabel 3. Rekapitulasi Presentase Kesalahan

\begin{tabular}{lc}
\hline Kesalahan pada tahap & Presentase \\
\hline Membaca & $13.0 \%$ \\
Pemahaman & $3.7 \%$ \\
Transformasi & $12.2 \%$ \\
Ketrampilan & $9.7 \%$ \\
Penulisan Jawaban akhir & $16.3 \%$ \\
Kecerobohan & $7.7 \%$ \\
\hline
\end{tabular}


Pada tabel 3 terlihat bahwa paling banyak kesulitan yang dialami siswa terjadi pada tahap pemahaman yaitu sebesar 13,0\%. Faktornya adalah siswa tidak menguasai rumus dan rencana untuk menyelesaikan soal cerita. Lalu di tahap penulisan jawaban akhir 16. 3\% hal ini disebabkan siswa menuliskan jawaban tanpa satuan dan serta tidak memberikan kesimpulan dari apa yang ditanyakan oleh soal.

Setelah mengidentifikasi hasil uji coba dan kesalahan siswa. peneliti mendapatkan data dan banyaknya siswa melakukan kesalahan dalam menyelesaikan soal cerita dalam beberapa jeni kesalahan. Kesalahan membaca soal (reading errors)dalam penelitian ini adalah kesalahan siswa tidak mampu memaknai symbol atau istilah yang terdapat pada soal serta tidak menguasai rumus dalam pengerjaan bangun ruang sisi datar gabungan.

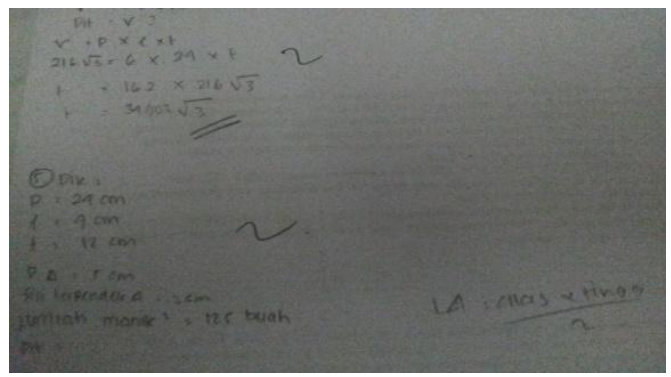

Gambar 1. Jawaban Siswa Nomor 5

Pada gambar 1 di atas terlihat bahwa siswa belum menguasai rumus dan belum tau cara pengerjaan atau perencanaan menyelesaikan soal. Kesalahan memahami masalah (comprehension errors) dalam penelitian ini adalah Siswa tidak bisa menyebutkan apa yang diketahui dengan lengkap. Ia tidak mengidentifikasi apa yang diketahui dengan tepat sehingga menyebabkan salah penafsiran serta tidak membaca soal dengan seksama sehingga ada informasi soal yang terlewat,tidak memahami arti keseluruhan soal dengan baik sehingga tidak konsisten dalam mengidentifikasi hal yang diketahui, tidak mampu menjelaskan informasi yang terdapat dalam soal dengan tepat.

Berikut disajikan hasil pekerjaan siswa dalam

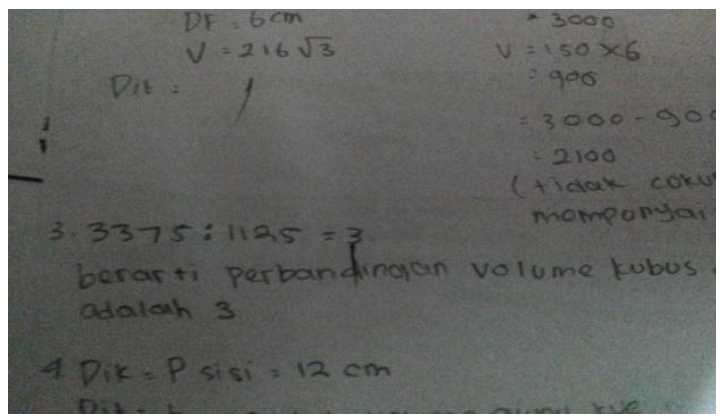

Gambar 2. Jawaban Siswa Nomor 3

Pada gambar 2 di atas terlihat bahwa siswa tidak menyebutkan apa yang diiketahui dan ditanyakan sehingga jawabannya belum tepat karena harusnya perbandingan tersebut 3 kali lipat volume kubus atau $3: 1$ dengan volume kubus.

Kesalahan transformasi (transformation errors) adalah kesalahan ini terjadi karena siswa tidak dapat merencanakan solusi untuk mengerjakan soal. Salah dalam menentukan rumus serta salah dalam menentukan operasi matematika yang digunakan. 


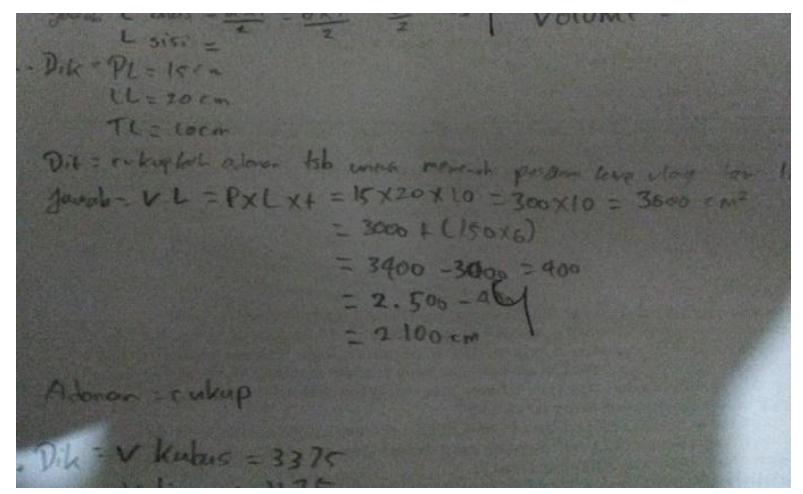

Gambar 3. Jawaban Siswa Nomor 2

Pada gambar 3 di atas terlihat bahwa siswa tidak menyelesaikan hasil pekerjaannya dengan bail masih belum bias merencanakan solusi dari persoalan kesalahan keterampilan proses (process skills errors) adalah kesalahan ini terjadi disaat siswa tidak menyadari melakukan kesalahan pada operasi hitung yang dilakukan dan tidak bisa melakukan operasi hitung dengan benar. Berikut disajikan hasil pekerjaan siswa yang melakukan kesalahan dalam operasi hitung. Berikut disajikan beberapa conth kesalahan siswa dalam keterampilan proses

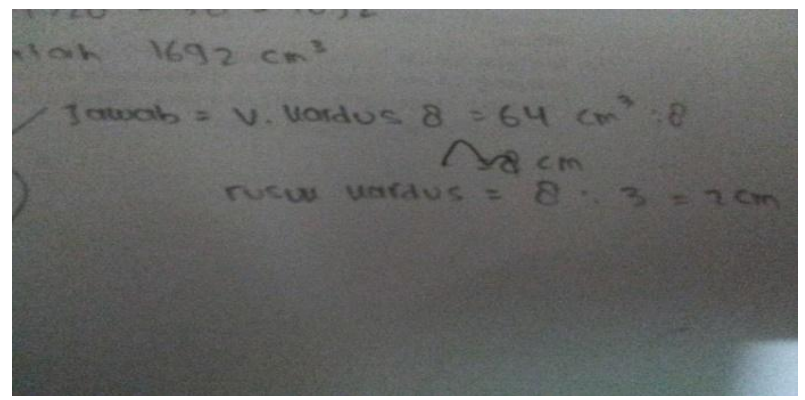

Gambar 4. Jawaban Siswa Nomor 6

Pada gambar 4 di atas terlihat bahwa siswa melakukan kesalahan dalam proses perhitungan atau operasi hitung sehngga jawababnnya salah dan tidak menyelesaikan hasil pekerjaannya,

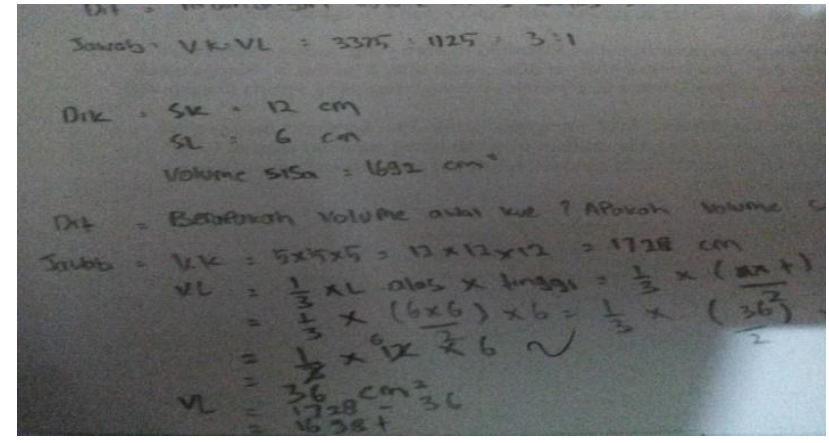

Gambar 5. Jawaban Siswa Nomor 4

Pada Gambar. 5 dapat terlihat pekerjaan siswa di atas terlihat bahwa siswa sebenarnya suah mengikuti prosedur pengerjaan soal namun diakhir pengerjaannya melakukan kesalahan dalam perhitungan ini disebaabkan kurang telitinya siswa dalam mengerjakan soal serta siswa tidak mengoreksi kembali hasil pekerjaanya. 


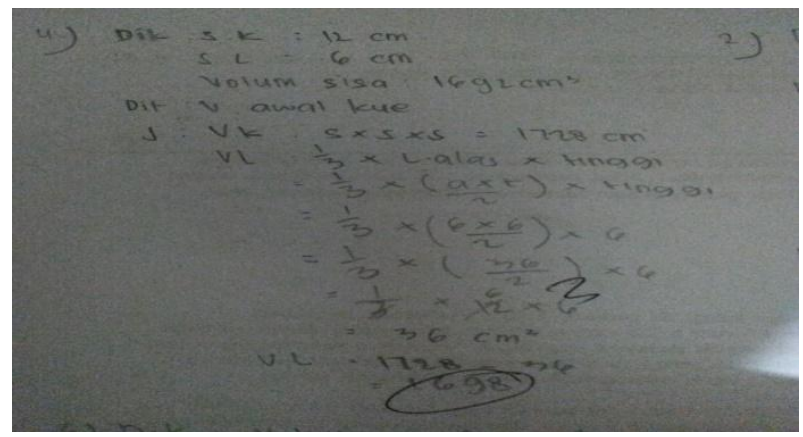

Gambar 6. Jawaban Siswa Nomor 4

Pada Gambar. 6 terlihat pekerjaan siswa di atas bahwa siswa melakukan kesalahan dalam perhitungan ini dan tidak menggunakan satuan yang ditanyakan. Serta dalam pengerjaannya tidak dilengkapi kesimpulan dari apa yang dditanyakan dalam soal.

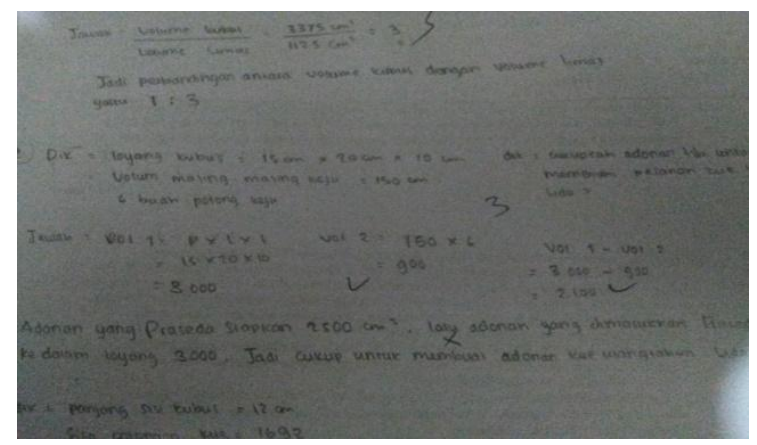

Gambar 7. Jawaban Siswa Nomor 2

Pada Gambar. 7 siswa melakukan kesalahan dalam menyimpulkan apa yang ditanyakan dalam soal Karena apabila dilihat proses sebelumnya sudah sesuai prosedur penyelesaian soal.

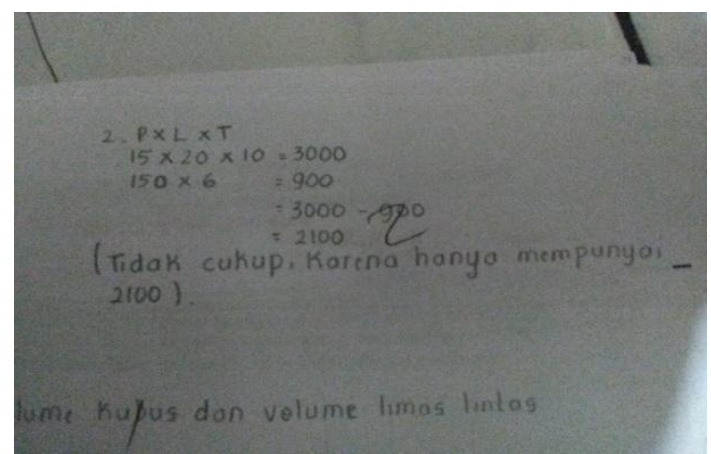

Gambar 8. Jawaban Siswa Nomor 2

Dari Gambar. 8 siswa melakukan kesalahan dalam menyimpulkan apa yang ditanyakan dalam soal Karena jawabannya tidak di cek kembali serta kurang ketelitian

\section{PEMBAHASAN}

Menurut Rindyana dan Chandra (2013), jenis-jenis kesalahan berdasarkan prosedur Newman yaitu kesalahan membaca soal (reading errors), kesalahan memahami masalah (comprehension errors), kesalahan transformasi (transformation errors), kesalahan keterampilan proses (process skills errors), dan kesalahan penulisan jawaban (encoding errors). Ditambahkan oleh Clements sebagaimana dikutip oleh rindyana dan chandra (2012:18), selain kelima kesalahan di atas yaitu kesalahan kecerobohan (careless errors). Hal ini sejalan dengan prosedur newman, hidayah mengemukakan jenis kesalahan Menurut hidayah (2016) Jenis kesalahan yang dimaksud yaitu: (1) kesalahan 
memahami soal, (2) kesalahan menyusun rencana, (3) kesalahan melaksanakan rencana, dan (4) kesalahan dalam memeriksa kembali solusi yang diperoleh.

Kesalahan penulisan jawaban (encoding errors) adalah Kesalahan yang dilakukan siswa dalam menuliskan jawaban akhir dapat berupa kesalahan dalam penyesuaian konteks atau kesalahan penulisan kata dan kalimat. Pada penelitian ini, kesalahan dalam penyesuaian konteks sering dilakukan siswa. Peneliti menemukan salah satu kesalahan jenis ini. Misal siswa menuliskan jawaban tanpa satuan dan tidak merujuk pada konteks permasalahan.

Kesalahan ini juga menurut Sangadah (2015) yaitu Jenis kesalahan process skills errors meliputi ommited data dan skills hierarchy problem dengan variasi kesalahan yang dilakukan siswa yaitu, salah dalam melakukan operasi hitung, tidak melakukan operasi untuk mencari nilai variabel sistem Persamaan Linear Dua Variabel atau tidak selesai dalam mengerjakan, sedangkan menurut Hidayanto,T. Subanji, \& Hidayanto, E (2017) permasalahan ini dikarenakan siswa melakukan miskonsepsi, kurangnya background pengetahuan dan penalaran, serta kesalahan pada perhitungan operasi dasar. Kesalahan kecerobohan (careless errors) adalah Tidak teliti dalam melakukan perhitungan. tidak mengecek kembali jawaban ujian sebelum dikumpulkan. serta tidak teliti dalam membaca hal yang diketahui.

Berdasarkan tujuan awal penelitian yaitu untuk menganalisis kesalahan siswa SMP kelas IX dalam menyelesaikan soal cerita kemampuan berpikir kritis matematis pada materi bangun ruang sisi datar, Berdasarkan hasil analisis data dan pembahasan hasil penelitian, maka dapat ditarik kesimpulan bahwa kesalahan yang dilakukan siswa dalam 6 aspek yaitu kesalahan membaca soal (reading errors), kesalahan memahami masalah (comprehension errors), kesalahan transformasi (transformation errors), kesalahan keterampilan proses (process skills errors), dan kesalahan penulisan jawaban (encoding errors) serta kesalahan kecerobohan (careless errors).

Berdasarkan hasil penelitian yang telah dilaksanakan, didapatkan beberapa saran yaitu Siswa diharapkan mempelajari materi bangun ruang sisi datar dengan baik agar memiliki kemampuan dalam menyelesaikan soal cerita yang bisa dikerjakan dengan berbagai rumus dan tidak salah memilih cara penyelesaian. Guru diharapkan lebih sering mengenalkan kalimat matematika supaya siswa terbiasa dengan kalimat matematika tersebut dan membiasakan siswa untuk menjawab dengan lengkap dan runtut atatu sistematis dalam soal-soal cerita matematika. Sebaiknya siswa lebih sering berlatih soal-soal cerita yang bervariasi. Mulai dari soal-soal cerita yang sederhana sampai dengan soa-lsoal cerita yang lebih kompleks dengan menekankan pada penggunaan langkah-langkah penyelesaian soal cerita agar siswa lebih terlatih dalam menyelesaikan soal cerita dan lebih sistematis. Guru diharapkan dapat menampung keluhan-keluhan siswa dalam menyelesaikan soal cerita matematika dan membantu kesulitan-kasulitan siswa tersebut supaya kesalahan-kesalahan dasar yang dilakukan siswa dapat dikurangi.

\section{REFERENSI}

Aripin, U., \& Purwasih, R. (2017). Penerapan Pembelajaran Berbasis Alternative Solutions Worksheet Untuk Meningkatkan Kemampuan Berpikir Kreatif. AKSIOMA: Jurnal Program Studi Pendidikan Matematika, 6 (2), 225-233.

Hendriana, H. (20140 Meningkatkan Kemampuan Kompetensi Strategis Matematis Siswa Sma Melalui Pembelajaran Berbasis Masalah. Prosiding Seminar Nasional Pendidikan Matematika ProgramPasca Sarjana STKIP Siliwangi Bandung. Volume 1, Tahun 2014. ISSN 23550473

Hidayah, S. (2016). Analisis Kesalahan Siswa Dalam Menyelesaikan Soal Cerita Spldv Berdasarkan Langkah Penyelesaian Polya. Prosiding Seminar Nasional Pendidikan Matematika 2016 Universitas Kanjuruhan Malang, Volume 1 Tahun 2016 - ISSN 2528-259X 
Hidayanto,T., Subanji \& Hidayanto, E (2017) . Deskripsi Kesalahan Struktur Berpikir Siswa SMP Dalam Menyelesaikan Masalah Geometri Serta Defragmentingnya: Suatu Studi Kasus. Jurnal Kajian Pembelajaran Matematika Vol. 1 No. 12017

Karnasih, I (2015). Analisis kesalahan Newman pada soal cerita matematis (Newman's Error Analysis in Mathematical Word Problems). Jurnal PARADIKMA, Vol. 8, Nomor 1, April 2015, Hal 37-51

Khatimah, K., Sa'dijah, C., \& Susanto, H (2017). Pemberian Scaffolding Untuk Mengatasi Hambatan Berpikir Siswa Dalam Memecahkan Masalah Aljabar. Jurnal Kajian Pembelajaran Matematika Vol. 1 No. 12017

Rindyana, B. S. B., \& Chandra, T. D. (2013). Analisis Kesalahan Siswa Dalam Menyelesaikan Soal Cerita Matematika Materi Sistem Persamaan Linear Dua Variabel Berdasarkan Analisis Newman. jurnal-online. um. ac. id

Royani, M. (2008). Pendekatan Realistik dalam Soal Cerita Pada Buku MatematikaSekolah Dasar. Jurnal Ilmiah Kependidikan dan Kemasyarakatan. Banjarmasin:STKIPPGRI

Sangadah, M. (2015). Analisis Kesalahan Siswa SMP Menyelesaikan Soal Matematika Pokok Bahasan Sistem Persamaan Linear Dua Variabel. Ekuivalen. 